\title{
Maximizing Social Equity as a Pillar of Public Administration: An Examination of Dispensary Licensing in Pennsylvania ${ }^{1}$
}

\author{
A. Lee Hannah ${ }^{2}$ \\ Wright State University \\ Daniel J. Mallinson ${ }^{3}$ \\ Penn State Harrisburg \\ Lauren Azevedo 4 \\ Penn State Harrisburg
}

\begin{abstract}
Public administration upholds four key pillars for administrative practice: economy, efficiency, effectiveness, and social equity. The question arises, however, how do administrators balance these often-competing priorities when implementing policy? Can the values which contributed to administrative decisions be measured? This study leverages the expansion of medical cannabis programs in the states to interrogate these questions. Focusing on the awarding of dispensary licenses in Pennsylvania affords the ability to determine the effect of social equity scoring on license award decision, relative to criteria that represent the other pillars of public administration. The results show that safety and business acumen were the most important determining factors in the awarding of licenses, both effectiveness and efficiency concerns. Social equity does not emerge as a significant determinant. This study then discusses the future of social equity provisions for cannabis policy, as well as what the findings mean for the social equity pillar in public administration.
\end{abstract}

\footnotetext{
${ }^{1}$ Prepared for the 2021 American Political Science Association Annual Meeting in Seattle, Washington, October 2, 2021.

${ }^{2}$ School of Public and International Affairs, Wright State University, Dayton, OH USA;

lee.hannah@wright.edu

${ }^{3}$ School of Public Affairs, Penn State Harrisburg, Harrisburg, PA USA; mallinson@psu.edu

${ }^{4}$ School of Public Affairs, Penn State Harrisburg, Harrisburg, PA USA; 1la41@psu.edu
} 
Four pillars undergird the profession of public administration: economy, effectiveness, efficiency, and social equity. Each are aims to which public sector professionals should strive. Alas, it is near impossible to maximize all these policy goals at one time (Stone 2012). This creates a fundamental dilemma for administrators implementing a myriad of policies. A question for researchers is whether such conflicts can be measured and compared to the goals established by political principles in statute. This study provides a test of these competing priorities through the implementation of medical cannabis policy in the American states.

Even though founding principles of United States democracy embrace freedom and equality, there is a long history of laws and policies that have promoted systematic exclusion and harmed marginalized communities. This has manifested in many ways, one of which includes American drug policy and mass incarceration (Alexander 2010). The War on Drugs has disproportionately impacted people of color, including racial disparities in arrests and sentencing of nonviolent crimes (Koch, Lee, and Lee 2016, Warde 2013). But the tide of drug policy in the United States began to change in the 1990s with the early adoption, and ongoing expansion, of medical marijuana by the states. To date, 38 states have acted in defiance of federal marijuana prohibition to adopt comprehensive medical marijuana programs, and 19 have adopted adult-use recreational programs. As the cannabis industry has grown and legalization became more popular there has been a growing call for social equity in cannabis policies (Kilmer 2019, Kilmer and Neel 2020). Social equity did not become a formal component of state cannabis policies until late in the spread of medical cannabis (Maryland's adoption in 2014), but it has become a core point of contention in debates over adult-use recreational programs.

This study leverages the history of social equity in medical cannabis policies to examine how administrators are affected by competing priorities when implementing public policy. 
Specifically, it examines the social equity process included in Pennsylvania's 2016 medical cannabis law and the subsequent awarding of cannabis dispensary licenses to determine which factors were most important for awarding those licenses: economy, efficiency, effectiveness, and/or social equity. More specifically, it seeks to better understand what specific factors were considered when administrators decided who receives a license, and if this resulted in equitable outcomes in the current Pennsylvania system. Ultimately, administrators appeared to be strategic in their balancing of these goals across the first and second waves of license awarding. Effectiveness was the clear goal in the first round, with the aim to rapidly stand up this brandnew industry. In the second round, social equity concerns did make an impact in choosing which applications received licenses. These findings provide implications for the field of public administration in practice and theory, specifically in terms of measurement of the social equity frontier in policy design. An examination of Pennsylvania medical cannabis laws offers unique understanding of equity in terms of socially vulnerable groups historically harmed by certain laws, industry diversity, licensing impacts, and offers suggestions for improvement in future policy designs to consider equitable outcomes.

This article begins by considering all four pillars of public administration, before narrowing into the more recent addition of the social equity pillar. It then provides a broad overview of social equity debates and provisions in state cannabis policy, as well as a specific description of Pennsylvania's process. All Phase 1 and Phase 2 dispensary application scorecards are used to determine which factors were most important for awarding licenses in Pennsylvania. The discussion of the results considers not only the implications for cannabis policy, but also for our understanding of the four pillars and the competing pressures they place on administrators. 


\section{THE FOUR PILLARS OF PUBLIC ADMINISTRATION}

Public administration has long upheld values such as the effective, efficient, and economical management of public services (Bryson, Crosby, and Bloomberg 2014). Before the 1960s, administrators were typically viewed as neutral arbiters of public programs who were to be kept away from partisan political influences (Wilson 1887). Professionals who are experts in their field and thus make expert and neutral decisions (Weber 2017 [1922]). The first three pillars of public administration: economy, efficiency, and effectiveness reflect this conceptualization of public servants seeking to implement maximally effective public programs while minimizing the costs of service. The Minnowbrook Conference in 1968, however, recognized that public administration, and its professionals, is not neutral. Attendants called for a "New Public Administration" that recognized the need for public administrators to be responsive to public demands, allow the public to participate in governmental decision making, seek social equity instead of perpetuating inequalities through bureaucratic neutrality, and more (Wooldridge and Gooden 2009). H. George Fredrickson became the most vocal advocate of the need for public administration to advance social equity. In his words, "Administrators are not

neutral. They should be committed to both good management and social equity as values, things to be achieved, or rationales" (Frederickson 2017, 283). Further, racial bias has long been an undercurrent in the "neutral" administrative state (House-Niamke and Eckerd 2021, Alexander and Stivers 2020).

It took over three decades for the National Academy of Public Administration to formally add social equity as the fourth pillar, and it is argued that the pillar has not yet been treated equally (Norman-Major 2011). Some have suggested that social equity is too underdeveloped to be a pillar (Durant and Rosenbloom 2017), and falls far behind effectiveness and efficiency in 
terms of performance management (Blessett, Fudge, and Gaynor 2017, Charbonneau et al. 2009). It is undoubtedly the case, however, that attention to social equity in public administration has surged in the last two decades (Svara and Brunet 2020). Shifting demographic trends and political landscapes in the US in addition to calls for fair access to programs is not the only reason for the focus on social equity in public administration. Polarization in political preferences, where the advantaged and disadvantaged are voting for contrasting initiatives, have made safety nets fall to government responsibility (McCarty, Poole, and Rosenthal 2016; Guy and McCandles 2008). Further, the promise of social equity argued by Guy and McCandless (2012) is all the more evident in public administration after the unrest in 2020 following the murder of George Floyd. Inequity in the delivery of public goods and services can no longer be ignored. Social equity, however, is not only a mindset of administrators, but also a key facet of policy design and implementation.

\section{SOCIAL EQUITY FOR POLICY ANALYSIS}

Frederickson (Frederickson 1974, 1990, 2017) highlights the importance of social equity as a pillar or critical value of public administration. According to Frederickson (Frederickson 2017), "the procedures of representative democracy presently operate in a way that either fails or only very gradually attempts to reverse systematic discrimination against disadvantaged minorities. Social equity, then, includes activities designed to enhance the political power and economic well-being of these minorities" (311). Thus, equity has to do with organizational fairness, management, and public service delivery that targets discrimination against underrepresented groups (Frederickson 2015, Riccucci 2009). In public policy, equity can be examined by understanding who receives what and under what rules decisions are made. 
Policy analysts have long evaluated issues of equity and fairness in different policy arenas (Blanchard 1986). Criteria required in pursuit of social equity includes procedural fairness, access, quality, and outcome (Guy and McCandless 2020). Equity can be a complicated term, as it does not necessarily mean equal but could be an amount based on need, ability to pay, or results achieved, among other indicators (Blanchard 1986). While social equity has evolved to include different definitions and implications, Frederickson's (2017) work highlighting its importance for society as a whole, in addition to more recent social equity work by Gooden (2014), Gooden and Portillo (2011), and Svara and Brunet (2020) suggest that equity centers on fair treatment, justice, and an equitable distribution of goods or services (Riccucci and Van Ryzin 2017).

Social equity can be operationalized in terms of procedural fairness, meaning equity in access and distribution of benefits or services, equity in benefit or service quality, equity in outcomes, and guaranteed expression of views (Svara and Brunet 2005). When there are gaps in these areas between groups, this is inequity (Johnson and Svara 2011). There is concern over equity in the policy process because of impacts on certain groups and on democracy more broadly (Schlozman, Verba, and Brady 1999). In sum, social equity is a measurable administrative goal (Guy and McCandless 2012) and thus scholars should be able to assess whether this goal motivates bureaucratic behavior.

\section{ADVANCING SOCIAL EQUITY}

One way to enhance social equity is through representative bureaucracy (Riccucci and Van Ryzin 2017). Representative bureaucracy theory suggests that including diverse representation in a public agency will ensure diverse voices are heard during decision-making (Bradbury and Kellough 2011, Mosher 1968). Representative bureaucracy has three commonly 
considered forms: active, passive, and symbolic representation. Mosher (1968) suggests the first way a bureaucracy can be representative is through passive representation, or when an agency has individuals represented from certain underrepresented groups. The second way an organization can be representative, according to Mosher (1968), is through active representation, which is when bureaucrats act in the best interest of those whom they represent. Active representation assumes individuals will make decisions in the best interest of their constituents because their decisions are representative of their social backgrounds (Krislov and Rosenbloom 1981, Meier 1993). More recent research has suggested that symbolic representation promotes certain policy outcomes through legitimacy and can provide further benefits to citizens by building trust among citizens (Riccucci and Van Ryzin 2017). Much of the public administration research on representative bureaucracy suggests expected links between active and passive representation, meaning that underrepresented group members are linked to bureaucratic outcomes that are consistent with the interests of those underrepresented groups (Bradbury and Kellough 2011, Keiser et al. 2002),

Another way to advance social equity is using rulemaking as a governance tool (Guy and McCandless 2020, Trochmann 2020). Rulemaking is an avenue to provide procedural fairness, or how an organization or agency follows statutory imperatives following due process, and process access, or how an agency ensures opportunities of participation can lead to desirable social outcomes (Trochmann 2020). According to Trochmann (2020), "Rulemaking processes foster deliberative democracy and values in deliberative democracy align with concepts of equity" (163). Similar to rulemaking, a third way to advance social equity is using choice points in a decision making framework (Blessett and Gaynor 2017). Choice points can promote equity by dissecting decisions looking at impacts, focusing on what obstructs or fosters equity. Choice 
points can counteract biases that may be present in policy-making and other decisions and offer a way to operationalize social equity in practice (Blessett and Gaynor 2017).

Representative bureaucracy, rulemaking, and choice points provide ways for marginalized voices to be added to policy debates and decisions to ensure quality and equitable programs and outcomes. In addition, they allow leaders to counteract implicit and explicit biases that may exist due to administrative decisions. In the case of Pennsylvania's medical cannabis program, architects of the law built in rulemaking procedures to include historically underrepresented groups in various choice points, including the ownership of cannabis growers, processors, and dispensaries. Before narrowing to the case of Pennsylvania, it is useful to first describe the broader landscape of social equity and legal cannabis.

\section{SOCIAL EQUITY AND LEGAL CANNABIS}

The cannabis industry, state regulators, and interest groups were slow to address the lack of diversity in the cannabis industry. Figure 1 illustrates the cumulative number of medical and recreational cannabis adoptions from 1996 to 2020. The blue line depicts the number of policies (medical and recreational) that include provisions for social equity, showing that early medical and recreational cannabis laws were silent on social equity. Maryland became the first state to add social equity to their medical marijuana bill in 2014. 
Figure 1: Cumulative Adoptions of Medical and Recreational Cannabis Laws (1996-2020)

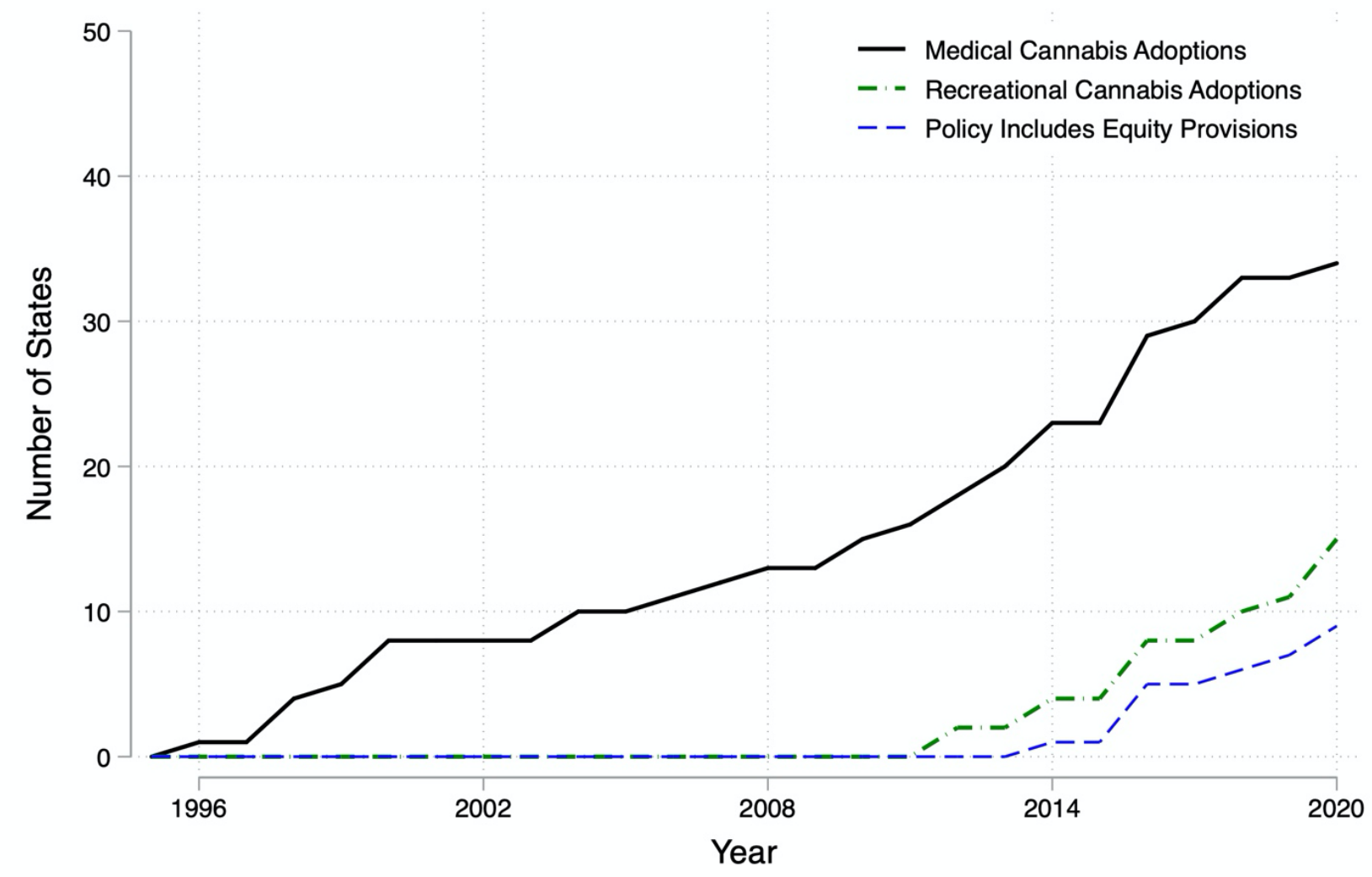

NOTE: 2020 data compiled by authors. Data from 1996 to 2019 from McVey (2019) of Marijuana Business Daily.

The delay in social equity is explained by a number of factors. First, prior to the Obama Administration's issuance of the Ogden Memo in 2009, states were wary to regulate cannabis beyond the public safety concerns (Mallinson, Hannah, and Cunningham 2020). Thus, states were particularly reluctant to "pick winners" when awarding licenses beyond ensuring safety and security. Second, the up-front cash required to succeed in the industry disproportionately favored white applicants (Neill Harris and Martin 2021). Moreover, by most accounts the pressures to get the programs off the ground pushed equity off of the agenda. As Ashley Kilroy, direct of Denver's Office of Marijuana Policy stated in an interview on PBS Newshour, "People didn't know what they didn't know at the time. I think [they] were just trying to get this passed and ... 
up and running" (quoted in Neill Harris and Martin $(2021,11)$ ). Third, addressing race in public administration has historically been "a nervous area of government" (Gooden 2014, 4). The rise of racial justice social movements like Black Lives Matter (founded in 2013) profoundly affected the public sphere and put the spotlight on issues connected to legal cannabis like racial injustices in policing and the larger judicial system.

The delay in including equity in legal cannabis bills contributes to an industry that is overwhelmingly white and wealthy. One of the most common provisions in early cannabis laws prohibited anyone convicted of marijuana offenses from being involved in the industry (or even being a patient in some medical cannabis states). This excluded people of color from capitalizing on the nascent industry given that underrepresented communities are disproportionately policed for nonviolent drug offenses (Baumgartner, Epp, and Shoub 2018, Alexander 2010). Restrictions in access to capital due to federal banking regulations serves as another barrier (Mallinson, Hannah, and Cunningham 2020). Many states included substantial capital requirements for dispensary and grower/processor license applicants. These requirements mean that applicants must have accesses to several hundred thousand dollars in liquid assets to qualify for a license (Harris and Martin 2021). Again, underrepresented communities have substantially smaller wealth and access to capital (Weller and Hanks 2018).

Social equity in cannabis policy includes both individual and structural barriers that can create unfair engagement or unjust outcomes and emphasizes inclusion of underrepresented groups in all aspects of the cannabis industry. Though varying greatly, cannabis policies that have addressed social equity tend to fall into five different areas: expungement of criminal records, protection of cannabis-legal activities, industry diversity, restorative justice funding, and curtailing risks of cannabis legalization in communities that were harmed by cannabis 
prohibition (Adinoff and Reiman 2019). Expungement policies are becoming the most prevalent, though many states have also tried to implement provisions to produce greater equity in the cannabis industry. Many of those policies have not succeeded (Adinoff and Reiman 2019).

Social equity can be constructed in terms of fairness and equality in distributing cannabis licenses across race, gender, and ethnic lines. More specifically, it can be examined through the degree to which licenses are fulfilled equally and fairly across groups and outcomes of these policies on different groups. Competing administrative priorities are part of the failure of efforts to include social equity in the administrative procedures designed to award dispensary licenses. Specifically, that even when applicants are evaluated on social equity, administrators place more value on effectiveness (both business and safety).

\section{SOCIAL EQUITY IN PENNSYLVANIA’S MEDICAL CANNABIS PROGRAM}

Social equity is being examined through cannabis policy by focusing on the current procedural policies in Pennsylvania's medical cannabis program that promote equity and examining the outcome of these policies. Pennsylvania adopted a comprehensive medical cannabis program (Act 16) in 2016 after years of largely partisan debate and stalemate were broken by key Republican political entrepreneurs in the General Assembly. Act 16 was novel in several respects. Most notably Pennsylvania became the first state to initiative a large-scale cannabis research enterprise across all its medical schools. Pennsylvania also joined Maryland in including social equity concerns in its statute. In Section 615 of Act 16, the General Assembly established its diversity goals and aims:

"It is the intent and goal of the General Assembly that the [Department of Health] promote diversity and the participation by diverse groups in the activities authorized under this act. In order to further this goal, the department shall adopt and implement policies ensuring the following: (1)That diverse groups are accorded equal opportunity in the permitting process. (2) That permittees promote the participation of diverse groups in 
their operations by affording equal access to employment opportunities." (Act 16 of 2016, Section 615(a)(1-2)).

Additionally, the law directed the Department of Health to conduct outreach to diverse communities as it established the program and its rule.

Current social equity policies in Pennsylvania include 1) the adoption of policies that offers opportunities for diverse groups during permitting, 2) promoting equitable work access to diverse groups; 3) outreach to diverse individuals by the Department of Health; 4) providing information on notice online; 5) offering application language for applicants to contract with diverse groups; 6) producing annual reports on participation of diverse groups used in permittees (PA Act 16 of 2016, Sec. 615). Pennsylvania aims to achieve these results through a scoring system, allocating 100 points for applicants' diversity plan out of a total of 1000 points. Diversity points are based on goals and summaries for diversity ownership, employment, and contracting. They must describe diversity goals, outreach events, mentoring and training, workforce percentages of diversity, and the utilization of contracts with small groups. Pennsylvania defines diverse groups as disadvantaged businesses, minority-owned businesses, women-owned businesses, and service-disabled veteran-owned or veteran-owned small businesses (Pennsylvania: Section 615(a-c)).

The Pennsylvania Department of Health issued guidance for Phase I of medical marijuana permits. During this phase, the department was set to issue up to 12 grower/processor permits and up to 27 dispensary permits. Within this number, companies could apply for one of five vertical integration permits, which would allow companies to control production, processing, and distribution (Twedt 2018). Applicants had to pay a $\$ 5,000$ nonrefundable fee in the initial application and would pay an additional $\$ 30,000$ per dispensary location if they won a certificate. The Board of Health divided the state into six Medical Marijuana regions and only 
made some counties eligible in the initial round. Table 1 summarizes each of the six regions and which counties were eligible in Phase I.

Table 1. Pennsylvania Medical Marijuana Regions

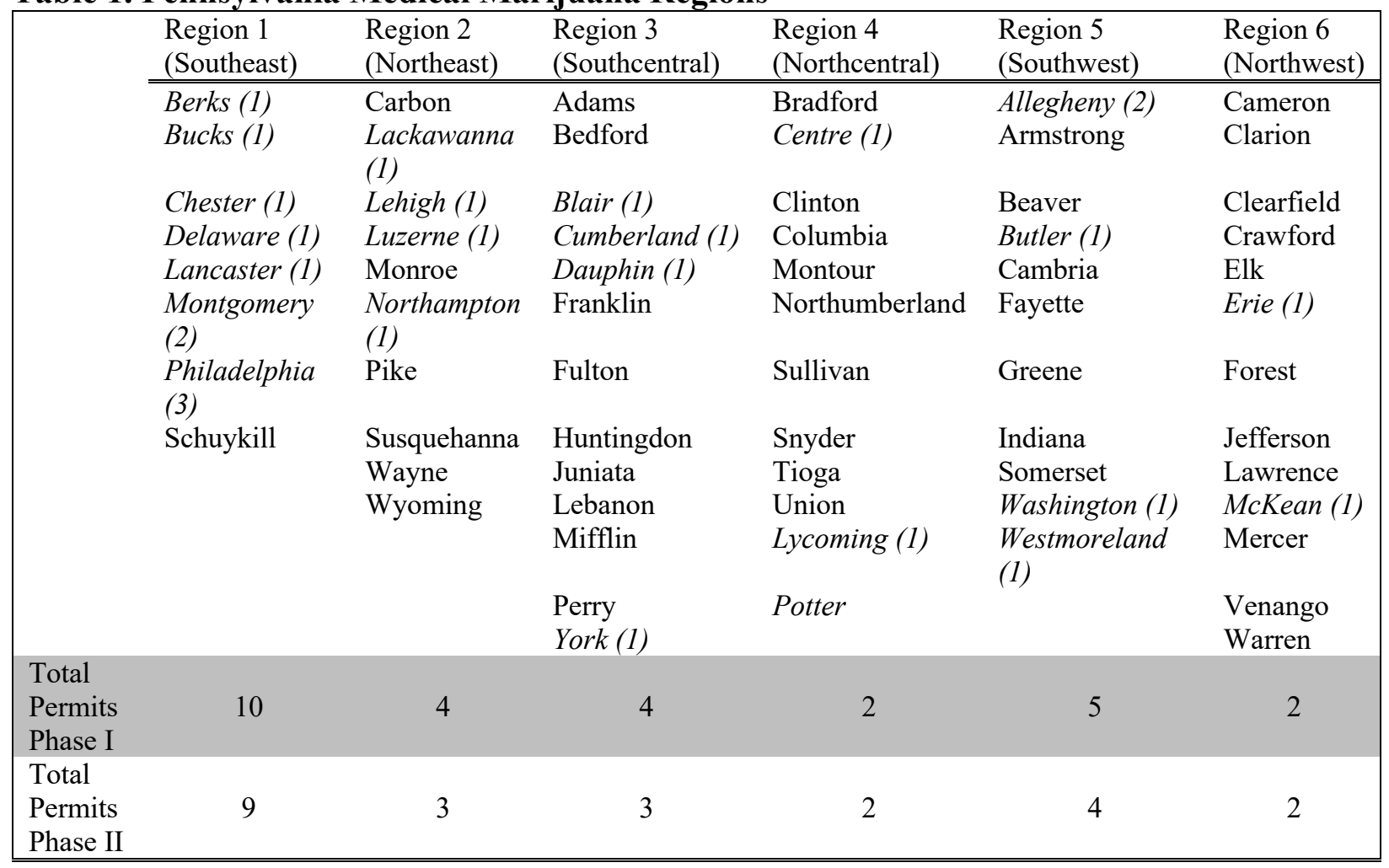

NOTE: Italicized counties indicate those in which an applicant for a dispensary permit is eligible in Phase 1 . The numbers in parentheses indicate the maximum number of dispensary locations for Phase I. In Phase II, the Department of Health established quotas per region, but not per county.

The scoring process of Phase I was heavily criticized. One hundred and forty of the 418 unsuccessful grower and dispensary applicants filed administrative appeals in the wake of the decisions. The complaints fall into three broad categories: 1) the form submission process, 2) inconsistent scoring of applications, and 3) opacity around the behind-the-scenes decision making and appeals process (Wagaman 2017).

The application process required forms and documentation that could total hundreds of pages. In a few documented instances, applications were ruled incomplete and not scored even though the law required that the department "shall notify" applicants if further documentation 
was required, as well as provide an additional 30 days for the applicants to complete the forms (Wagaman 2017).

For the applications that were scored, the scores were criticized for inconsistencies and ambiguity. The Health Department refused to disclose the names or level of expertise of the state employees that scored the applications (Couloumbis 2017). For example, the capital requirements section required dispensaries to document at least $\$ 150,000$ in financial backing. It was unclear whether more financial backing would lead to higher scores or if dispensaries just needed to show that they were above the threshold. However, at the scoring phase, the committee ended up scoring on a sliding scale based on how much cash the dispensaries had. Meanwhile, applicants were required to file the personal identification (photo IDs and resumes) of each financial backer, operator, and employee. The Health Department ended up scoring this section based on the quality of resumes and photos. There were also examples of companies filing multiple and identical applications, only to have sections scored differently with no explanation. The Department of Health responded that compliance with the Medical Marijuana Act is solely their responsibility and "is accomplished in the sole exercise of the discretion of the Office" (Wagaman 2017).

\section{DATA AND METHODS}

The primary data for this study is drawn from the universe of Pennsylvania's Phase 1 and Phase 2 dispensary application report cards from the Department of Health. ${ }^{5}$ Parts B, D, E, F, and Attachments D and E of the state's dispensary application were each assigned points for DOH evaluation totaling 1,000 points. Part B evaluated the applicant's diversity plan, with a

\footnotetext{
${ }^{5}$ https://www.health.pa.gov/topics/programs/Medical\%20Marijuana/Pages/Phase-l.aspx; https://www.health.pa.gov/topics/programs/Medical\%20Marijuana/Pages/Phase-Il.aspx.
} 
maximum of 100 points. Part D pertained to the applicant's plan of operation and represents 550 total points in Phase I and 675 points in Phase II. Part E includes the applicant's organization, ownership, capital, and tax status, for 150 total points in Phase I and 75 points in Phase II. Part F assigns 100 points for the licensee's expected community impact. Attachment $\mathrm{D}$ includes the applicant's site and facility plan (50 points) and Attachment E included the applicant's personal identification worth 50 points in Phase I and was not included in Phase II. Table 2 presents a copy of the scorecard and its components for each phase. The Department of Health scored 251 applications and awarded 27 licenses in Phase I and scored an additional 225 applications and awarded 23 licenses in Phase II. Applicants could apply for permits for up to three dispensaries under one application in Phase I and up to two dispensaries per application in Phase II. ${ }^{6}$

\footnotetext{
${ }^{6}$ Medical Marijuana Organization Permit Application Phase I: http://media.philly.com/documents/Medical+Marijuana+Application Instructions-Phase+1 b 17-Jan-17.pdf; Phase II: https://www.health.pa.gov/topics/Documents/Programs/Medical\%20Marijuana/DOH\%20\%20Instructions\%20Phase\%20ll.pdf.
} 
Table 2. Example Pennsylvania Department of Health Medical Marijuana Dispensary Application Scorecard

\begin{tabular}{|c|c|c|}
\hline Dispensary Application Scoring & $\begin{array}{l}\text { Maximum Points } \\
\text { Phase } 1\end{array}$ & $\begin{array}{l}\text { Maximum Points } \\
\text { Phase } 2\end{array}$ \\
\hline \multicolumn{3}{|c|}{ Part B - Diversity Plan } \\
\hline 3 - Diversity Plan & 100 & 100 \\
\hline \multicolumn{3}{|c|}{ Part D - Plan of Operation } \\
\hline 8 -Operational Timetable & 100 & 100 \\
\hline $\begin{array}{l}9 \text { - Employee Qualifications, } \\
\text { Description of Duties and Training }\end{array}$ & 50 & 50 \\
\hline $10-$ Security and Surveillance & 100 & 100 \\
\hline $\begin{array}{l}11-\text { Transportation of Medical } \\
\text { Marijuana }\end{array}$ & 25 & 50 \\
\hline 12 - Storage of Medical Marijuana & 50 & 75 \\
\hline 13 - Labeling of Medical Marijuana & 25 & -- \\
\hline 14 - Inventory Management & 50 & 75 \\
\hline 15 - Diversion Prevention & 50 & 100 \\
\hline $16-$ Sanitation and Safety & 50 & 50 \\
\hline 17 - Recordkeeping & 50 & 75 \\
\hline \multicolumn{3}{|c|}{ Part E - Applicant Organization, Ownership, Capital and Tax Status } \\
\hline $\begin{array}{l}19-\text { Business History and Capacity to } \\
\text { Operate }\end{array}$ & 75 & 75 \\
\hline 22 - Capital Requirements & 75 & -- \\
\hline \multicolumn{3}{|c|}{ Part F - Community Impact } \\
\hline $23-$ Community Impact & 100 & 100 \\
\hline \multicolumn{3}{|c|}{ Attachments } \\
\hline Attachment D: Site and Facility Plan & 50 & 50 \\
\hline Attachment E: Personal Identification & 50 & -- \\
\hline Total & 1,000 & 1,000 \\
\hline
\end{tabular}

The analysis of the scorecards begins descriptively, with examining the distribution of scores for dispensary applications across each of the five major scored components in Phases I and II. Winning applications are highlighted within each. After visualizing these distributions, the analysis in a multi-step fashion to identify which factors contributed the most to the awarding of licenses. This begins with a series of bivariate logistic regression models that use the awarding of a license as the dependent variable. Not only are odds ratios calculated, but pseudo- $\mathrm{R}^{2}$ values are compared to give a first impression at which components of the application explain the most 
variance in the awarding of licenses. This is done separately for Phase I and Phase II due to changes in the scorecard between the phases.

Multivariate logistic regressions are then estimated to compare the relative effects of each scoring component, in particular social equity, in Phases I and II awarding. Parts D and E were collapsed into additive indices for Phase I and Part D was so collapsed for Phase II. Part C (diversity plan), Part F (community impact), and the site plan remained a single item in Phase 1 and Part E (applicant organization) was also a single scored item in Phase II. This allows for a comparison of each major component and its relative weight in the awarding of licenses. Again, the multivariate models are estimated separately for Phases I and II. Finally, predicted probabilities plots demonstrate how the probability of license awarding in Phases I and II changes across each of the components, giving a sense of the non-linear relationship between scores and the probability of being awarded a license, as well as a comparison of the effects of each component in Phases I and II.

Implementers likely had to make trade-offs in considering economy, efficiency, effectiveness, and social equity in the awarding of dispensary licenses. Given the multi-stage process of awarding licenses, bureaucrats may have been strategic in how they weighed each of the pillars. Social equity is difficult to measure (Svara and Brunet 2005) and confusion in measuring and comparing criteria linked to the pillars create an opening for bureaucrats to be strategic in how they weigh competing goals (Gooden and Myers 2004). Given the scrutiny over marijuana legalization in the United States, it is likely that effectiveness is the most important pillar in Phase I awarding, because implementors want to stand up a fully functional program as 
quickly as possible. Phase II awarding then allows for other dimensions like social equity to play a greater role in awarding. This leads to two hypotheses:

Hypothesis 1: Effectiveness will be a key component of dispensary license awarding in Phase I.

Hypothesis 2: Social equity will be a key component of dispensary license awarding in Phase II.

\section{RESULTS}

DOH's scorecards and assigned scores for each component reveal the key values behind the licensing process. According to the maximum possible scores, a dispensary applicant's diversity plan and community impact each account for $10 \%$ of the application, respectively, whereas the plan of operation accounts for 55\% of the points in Phase I and 67.5\% in Phase II. To an extent, this already over-weights awarding towards concerns of effectiveness over social equity, however the distributions of the actual scores offer initial insight into which factors are most important for the winning applications. In general, DOH awarded licenses to the top scoring candidates after considering region and county.

Figures 2 and 3 show the distributions of each score. In Figure 2, the 27 dispensaries that were awarded licenses are marked in blue and in Figure 3 the 23 awarded licenses are marked in red. Additionally, Table 3 provides the average awarded points per section of the scorecards for each phase. For Phase I (Figure 2 and Table 3) the diversity plans (Part C) of the winning applicants averaged 51 points compared to an average score of 40 for the losing applicants ( 9 percent difference). The plan of operations (Part D) averaged 362 points out of 550 for the 
winning applicants compared to 295 for the losing applicants (12 percent difference). The applicant organization (Part E) scores ranged from 101 out of 150 for the losing candidates to 124 for the winning candidates (a 15 percent difference). Finally, the community impact plans (Part F) of the winning applicants averaged 51 points compared to 43 points for the losing applicants (8 percent difference).

Figure 2. Distribution of Scores for Pennsylvania Dispensary Applications (Phase I)
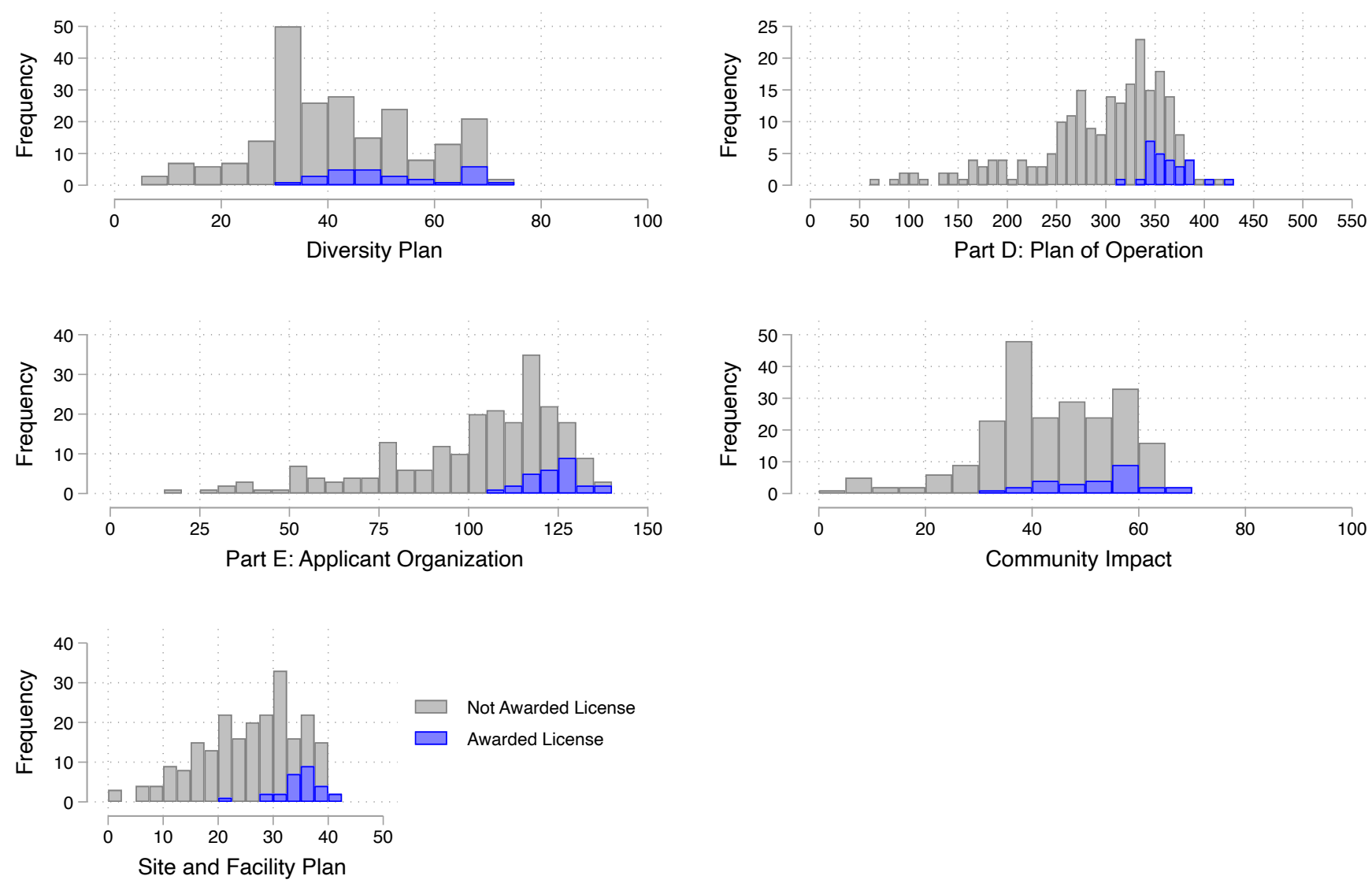
Figure 3. Distribution of Scores for Pennsylvania Dispensary Applications (Phase II)
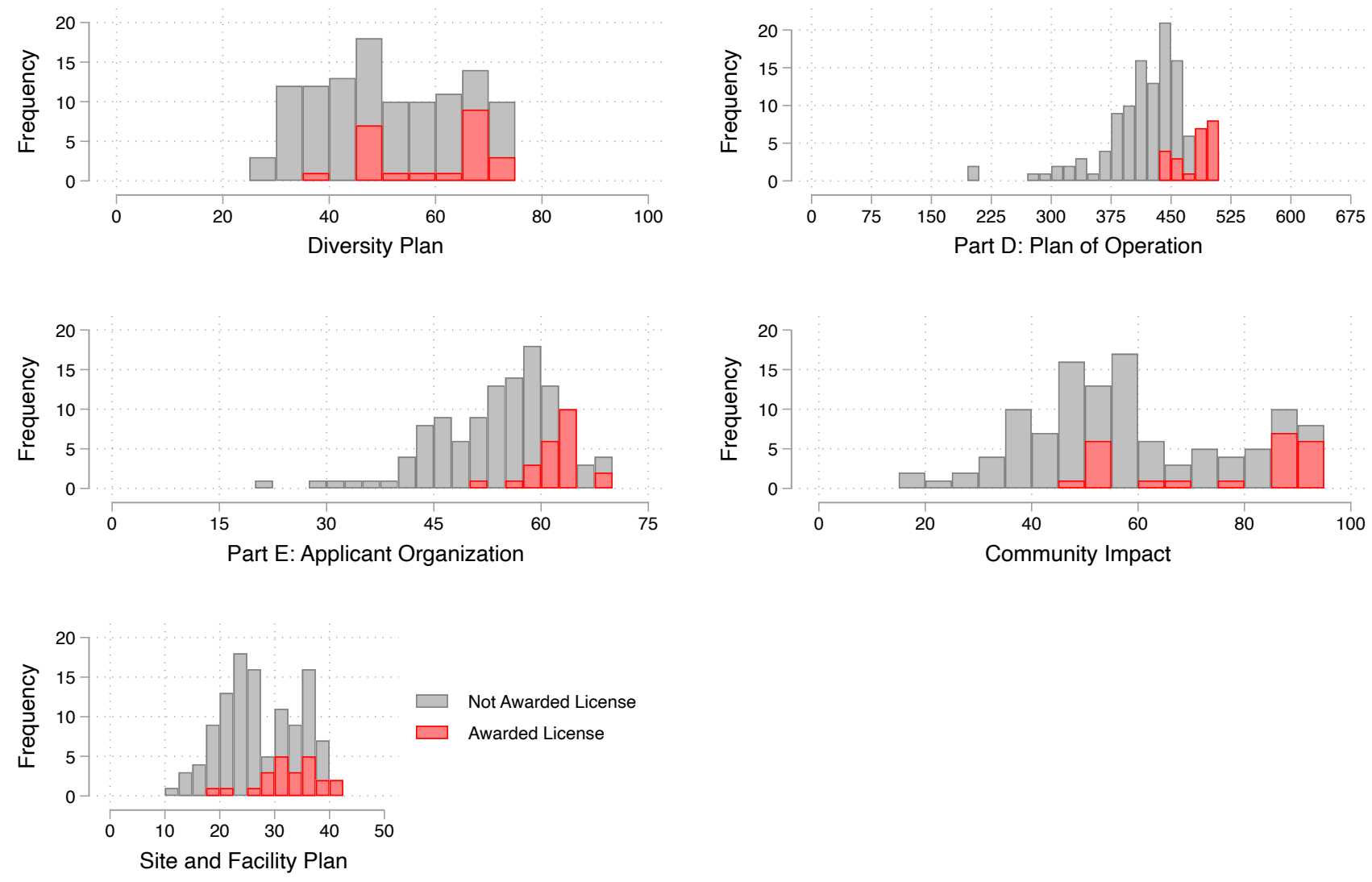
Table 3. PA Dept. of Health Medical Marijuana Dispensary Application Scorecard - Average Scores in Each Category (Red text denotes changes in scoring from Phase I to Phase II)

\begin{tabular}{|c|c|c|}
\hline Dispensary Application Scoring & Average Points (Phase I) & Average Points (Phase II) \\
\hline \multicolumn{3}{|l|}{ Part B - Diversity Plan } \\
\hline 3 - Diversity Plan & $\begin{array}{c}41 / 100 \\
{[\mathrm{NP}: 40, \mathrm{P}: 51]}\end{array}$ & $\begin{array}{c}51 / 100 \\
{[N P: 50, P: 59]}\end{array}$ \\
\hline Part D - Plan of Operation & $\begin{array}{c}302 / 550 \\
{[N P: 295, P: 362]}\end{array}$ & $\begin{array}{c}427 / 675 \\
{[N P: 417, P: 480]} \\
\end{array}$ \\
\hline 8 - Operational Timetable & $\begin{array}{c}51 / 100 \\
{[\mathrm{NP}: 49, \mathrm{P}: 64]}\end{array}$ & $\begin{array}{c}58 / 100 \\
{[\mathrm{NP}: 56, \mathrm{P}: 68]}\end{array}$ \\
\hline $\begin{array}{l}\text { 9- Employee Qualifications, Description of Duties } \\
\text { and Training }\end{array}$ & $\begin{array}{c}31 / 50 \\
{[\mathrm{NP}: 30, \mathrm{P}: 36]}\end{array}$ & $\begin{array}{c}31 / 50 \\
{[\mathrm{NP}: 31, \mathrm{P}: 34]}\end{array}$ \\
\hline $10-$ Security and Surveillance & $\begin{array}{c}58 / 100 \\
{[\mathrm{NP}: 56, \mathrm{P}: 68]}\end{array}$ & $\begin{array}{c}62 / 100 \\
{[\mathrm{NP}: 61, \mathrm{P}: 69]} \\
\end{array}$ \\
\hline 11 - Transportation of Medical Marijuana & $\begin{array}{c}15 / 25 \\
{[\mathrm{NP}: 15, \mathrm{P}: 18]}\end{array}$ & $\begin{array}{c}31 / 50 \\
{[\mathrm{NP}: 30, \mathrm{P}: 35]}\end{array}$ \\
\hline 12 - Storage of Medical Marijuana & $\begin{array}{c}28 / 50 \\
{[N P: 27, P: 34]}\end{array}$ & $\begin{array}{c}48 / 75 \\
{[\mathrm{NP}: 47, \mathrm{P}: 55]} \\
\end{array}$ \\
\hline 13 - Labeling of Medical Marijuana & $\begin{array}{c}15 / 25 \\
{[\mathrm{NP}: 15, \mathrm{P}: 18]}\end{array}$ & -- \\
\hline 14 - Inventory Management & $\begin{array}{c}30 / 50 \\
{[\mathrm{NP}: 29, \mathrm{P}: 35]}\end{array}$ & $\begin{array}{c}50 / 75 \\
{[N P: 49, P: 55]} \\
\end{array}$ \\
\hline 15 - Diversion Prevention & $\begin{array}{c}29 / 50 \\
{[N P: 29, P: 35]}\end{array}$ & $\begin{array}{c}64 / 100 \\
{[N P: 62, P: 71]} \\
\end{array}$ \\
\hline $16-$ Sanitation and Safety & $\begin{array}{c}29 / 50 \\
{[\mathrm{NP}: 28, \mathrm{P}: 35]} \\
\end{array}$ & $\begin{array}{c}32 / 50 \\
{[\mathrm{NP}: 31, \mathrm{P}: 36]} \\
\end{array}$ \\
\hline 17 - Recordkeeping & $\begin{array}{c}16 / 50 \\
{[N P: 16, P: 19]}\end{array}$ & $\begin{array}{c}52 / 75 \\
{[\mathrm{NP}: 51, \mathrm{P}: 56]}\end{array}$ \\
\hline $\begin{array}{l}\text { Part E-Applicant Organization, Ownership, } \\
\text { Capital and Tax Status }\end{array}$ & $\begin{array}{c}104 / 150 \\
{[N P: 101, P: 124]} \\
\end{array}$ & $\begin{array}{r}55 / 75 \\
{[\mathrm{NP}: 54, \mathrm{P}: 62]} \\
\end{array}$ \\
\hline 19 - Business History and Capacity to Operate & $\begin{array}{c}50 / 75 \\
{[\mathrm{NP}: 49, \mathrm{P}: 61]}\end{array}$ & $\begin{array}{c}55 / 75 \\
{[\mathrm{NP}: 54, \mathrm{P}: 62]}\end{array}$ \\
\hline 22 - Capital Requirements & $\begin{array}{c}53 / 75 \\
{[N P: 52, P: 62]}\end{array}$ & -- \\
\hline \multicolumn{3}{|l|}{ Part F - Community Impact } \\
\hline 23 - Community Impact & $\begin{array}{c}44 / 100 \\
{[N P: 43, P: 51]}\end{array}$ & $\begin{array}{c}60 / 100 \\
{[N P: 57, P: 75]}\end{array}$ \\
\hline \multicolumn{3}{|l|}{ Attachments } \\
\hline Attachment D: Site and Facility Plan & $\begin{array}{c}27 / 50 \\
{[\mathrm{NP}: 26, \mathrm{P}: 35]} \\
\end{array}$ & $\begin{array}{c}28 / 50 \\
{[\mathrm{NP}: 27, \mathrm{P}: 32]} \\
\end{array}$ \\
\hline Attachment E: Personal Identification & $\begin{array}{c}33 / 50 \\
{[\mathrm{NP}: 33, \mathrm{P}: 38]} \\
\end{array}$ & -- \\
\hline Total & $\begin{array}{c}551 / 1,000 \\
{[\mathrm{NP}: 538, \mathrm{P}: 662]}\end{array}$ & $\begin{array}{c}622 / 1,000 \\
{[\mathrm{NP}: 605, \mathrm{P}: 708]}\end{array}$ \\
\hline Number of Applications Scored & 251 & 136 \\
\hline Number of Licenses Awarded & 26 & 23 \\
\hline
\end{tabular}

${ }^{*} \mathrm{NP}=$ No Permit; $\mathrm{P}=$ Permitted 
For Phase II (Figure 3 and Table 3 ) the diversity plans of the winning applicants improved to 68 points compared to 56 points for losing applicants (12 percent difference). The plan of operations averaged 480 out of 675 total points for winning applicants compared to 417 for losing applicants (nine percent difference). The applicant organization scores ranged from 54 out of 75 for the losing applicants to 62 for the winning applicants (11 percent difference) Finally, the community impact plans increased the most from Phase I to Phase II, with winning applicants scoring 75 points on average compared to losing applicants scoring 57 points (higher than the average winning applicant in Phase I). The 18 percentage point gap between the average winning and average losing community plan was also the widest within the categories for either phase.

\section{BIVARIATE ANALYSIS}

To begin assessing the relative weight of each component of the scorecards in license awarding, the results of the series of bivariate logistic regressions are presented in Table 4. In Phase I, business history and the dispensary's proposed site and facility plan explain the most variance in the awarding of licenses (pseudo- $\mathrm{R}^{2}=0.22$ ). Both concern the potential effectiveness of a dispensary applicant. Conversely, an applicant's diversity plan and community impact, each tied to social equity, explain the lowest variance (pseudo- $\mathrm{R}^{2}=0.07$ and 0.08 , respectively). In Phase II, considerations regarding transportation, security and surveillance, storage, and diversion prevention, are the strongest predictors of dispensary awarding. Each are components of effectiveness, but of a different kind. Namely, they capture concerns about safety and security instead of business acumen. Diversity plans have a similarly low predictive power, but the pseudo- $\mathrm{R}^{2}$ for community impact does increase in Phase II (0.12). 
Table 4: Bivariate Logistic Regressions Predicting Odds of Being Awarded a Dispensary License (Phases I and II)

\begin{tabular}{|c|c|c|c|c|}
\hline & \multicolumn{2}{|c|}{ PHASE I } & \multicolumn{2}{|c|}{ PHASE II } \\
\hline Application & $\begin{array}{c}\text { Odds Ratio } \\
\text { [Confidence } \\
\text { Intervals in } \\
\text { Brackets] }\end{array}$ & Pseudo $\mathrm{R}^{2}$ & $\begin{array}{c}\text { Odds Ratio } \\
\text { [Confidence } \\
\text { Intervals in } \\
\text { Brackets] }\end{array}$ & Pseudo $\mathrm{R}^{2}$ \\
\hline 3 - Diversity Plan & $\begin{array}{c}1.05 \\
{[1.02-1.08]}\end{array}$ & 0.07 & $\begin{array}{c}1.05 \\
{[1.02-1.10]}\end{array}$ & 0.07 \\
\hline \multicolumn{5}{|c|}{ Part D - Plan of Operation } \\
\hline 8 - Operational Timetable & $\begin{array}{c}1.08 \\
{[1.04-1.12]}\end{array}$ & 0.14 & $\begin{array}{c}1.12 \\
{[1.05-1.19]}\end{array}$ & 0.17 \\
\hline $\begin{array}{l}\text { 9-Employee } \\
\text { Qualifications, }\end{array}$ & $\begin{array}{c}1.25 \\
{[1.12-1.39]}\end{array}$ & 0.15 & $\begin{array}{c}1.17 \\
{[1.04-1.32]}\end{array}$ & 0.07 \\
\hline $\begin{array}{l}10-\text { Security and } \\
\text { Surveillance }\end{array}$ & $\begin{array}{c}1.17 \\
{[1.09-1.26]}\end{array}$ & 0.18 & $\begin{array}{c}1.31 \\
{[1.16-1.47]}\end{array}$ & 0.28 \\
\hline 11 - Transportation & $\begin{array}{c}1.57 \\
{[1.26-1.96]}\end{array}$ & 0.15 & $\begin{array}{c}1.77 \\
{[1.37-2.29]}\end{array}$ & 0.33 \\
\hline 12 - Storage & $\begin{array}{c}1.30 \\
{[1.15-1.46]}\end{array}$ & 0.18 & $\begin{array}{c}1.34 \\
{[1.18-1.53]}\end{array}$ & 0.28 \\
\hline 13 - Labeling & $\begin{array}{c}1.48 \\
{[1.22-1.79]}\end{array}$ & 0.14 & -- & -- \\
\hline $\begin{array}{l}14-\text { Inventory } \\
\text { Management }\end{array}$ & $\begin{array}{c}1.27 \\
{[1.13-1.44]}\end{array}$ & 0.15 & $\begin{array}{c}1.28 \\
{[1.14-1.44]}\end{array}$ & 0.21 \\
\hline 15 - Diversion Prevention & $\begin{array}{c}1.27 \\
{[1.13-1.43]}\end{array}$ & 0.16 & $\begin{array}{c}1.27 \\
{[1.14-1.40]}\end{array}$ & 0.26 \\
\hline $16-$ Sanitation and Safety & $\begin{array}{c}1.25 \\
{[1.12-1.39]}\end{array}$ & 0.15 & $\begin{array}{c}1.29 \\
{[1.11-1.51]}\end{array}$ & 0.14 \\
\hline 17 - Recordkeeping & $\begin{array}{c}1.45 \\
{[1.18-1.77]}\end{array}$ & 0.12 & $\begin{array}{c}1.21 \\
{[1.07-1.37]}\end{array}$ & 0.12 \\
\hline \multicolumn{5}{|c|}{ Part E - Applicant Organization, Ownership, Capital and Tax Status } \\
\hline 19 - Business History & $\begin{array}{c}1.23 \\
{[1.12-1.36]}\end{array}$ & 0.22 & $\begin{array}{c}1.23 \\
{[1.11-1.36]}\end{array}$ & 0.20 \\
\hline $\begin{array}{l}22 \text { - Capital } \\
\text { Requirements }\end{array}$ & $\begin{array}{c}1.15 \\
{[1.07-1.23]}\end{array}$ & 0.15 & -- & -- \\
\hline \multicolumn{5}{|c|}{ Part F - Community Impact } \\
\hline 23 - Community Impact & $\begin{array}{c}1.07 \\
{[1.03-1.12]}\end{array}$ & 0.08 & $\begin{array}{c}1.05 \\
{[1.02-1.07]}\end{array}$ & 0.12 \\
\hline \multicolumn{5}{|c|}{ Attachments } \\
\hline Site and Facility Plan & $\begin{array}{c}1.25 \\
{[1.13-1.38]}\end{array}$ & 0.22 & $\begin{array}{c}1.12 \\
{[1.04-1.21]}\end{array}$ & 0.09 \\
\hline Personal Identification & $\begin{array}{c}1.42 \\
{[1.21-1.67]}\end{array}$ & 0.19 & -- & -- \\
\hline$N$ & 251 & & 136 & \\
\hline
\end{tabular}




\section{MULTIVARIATE ANALYSIS}

Table 5 presents the results of two multivariate logistic regression models, one each for Phases I and II. Odds ratios are reported for easier interpretation of the results. An odds ratio over 1 represents a component that increases the odds of being awarded a license. In Phase I, the applicant's plan of operation (Part D) and site plan were the only two statistically significant predictors of receiving a license. For each additional point awarded for a site plan, the odds of receiving a license increased by 14 percent. It is a two percent increase for each additional point on the plan of operations, but recall that this section of the scorecard represents over half of the total points. Turning to Phase II, the plan of operations is still a significant predictor of awarding, but both diversity plans (Part C) and community impacts (Part F) are statistically significant. For each additional point on the diversity plan score, the odds of receiving a license increase by nine percent. For community impact it is six percent.

Table 5: Multivariate Logistic Regressions Predicting Odds of Being Awarded a Dispensary License (Phases I and II)

\begin{tabular}{|l|c|c|}
\hline & Phase I & Phase II \\
\hline & Odds Ratio & Odds Ratio \\
& {$[$ Confidence Intervals in Brackets] } & [Confidence Intervals in Brackets] \\
\hline Part C - Diversity Plan & 1.02 & $\mathbf{1 . 0 9}$ \\
& {$[0.98-1.06]$} & {$[\mathbf{1 . 0 1}-\mathbf{1 . 1 7}]$} \\
\hline Part D - Plan of Operation & $\mathbf{1 . 0 2}$ & $\mathbf{1 . 0 6}$ \\
& {$[\mathbf{1 . 0 0 - 1 . 0 5}]$} & {$[\mathbf{1 . 0 3 - 1 . 0 9 ]}$} \\
\hline Part E - Applicant Organization & 1.05 & 1.05 \\
& {$[0.98-1.12]$} & {$[0.90-1.24]$} \\
\hline Part F - Community Impact & 0.99 & $\mathbf{1 . 0 6}$ \\
& {$[0.94-1.04]$} & {$[\mathbf{1 . 0 2}-\mathbf{1 . 1 0}]$} \\
\hline Site Plan & $\mathbf{1 . 1 4}$ & 1.00 \\
& {$[\mathbf{1 . 0 3 - 1 . 1 2}]$} & {$[0.89-1.12]$} \\
\hline $\mathrm{N}$ & 251 & 136 \\
\hline Pseudo $\mathrm{R}^{2}$ & 0.31 & 0.51 \\
\hline $\mathrm{X}^{2}$ & 53.92 & 63.39 \\
\hline
\end{tabular}

To better interpret these results, as well as draw comparisons between Phases I and II, Figures 4 and 5 present the changes in predicted probabilities for each scorecard component in 
Phases I and II. In Figures $4 \mathrm{a}$ and 4b, it is evident that the probability of awarding increases rapidly for additional diversity plan and community impact points in Phase II, but not Phase I. Granted, even when receiving the maximum points for each, the probability of receiving a license increases to only 0.5 and 0.3 , respectively. For an applicant's plan of operations, however, achieving the highest scores nearly guarantees a license in Phase 2 (Figure 5a). Though Part E (business history) is not statistically significant in either model, the predicted probabilities do show a substantial non-linear change in probabilities in Phase I awarding (Figure 5b). It is only when awarded points reach 75 and higher that this component begins to help an applicant. Finally, Figure $4 c$ confirms the positive effect of site and facility plans in Phase I, but not Phase II awarding.

Figure 4: Predicted Probabilities of Winning Dispensary License based on Diversity and Community Plans
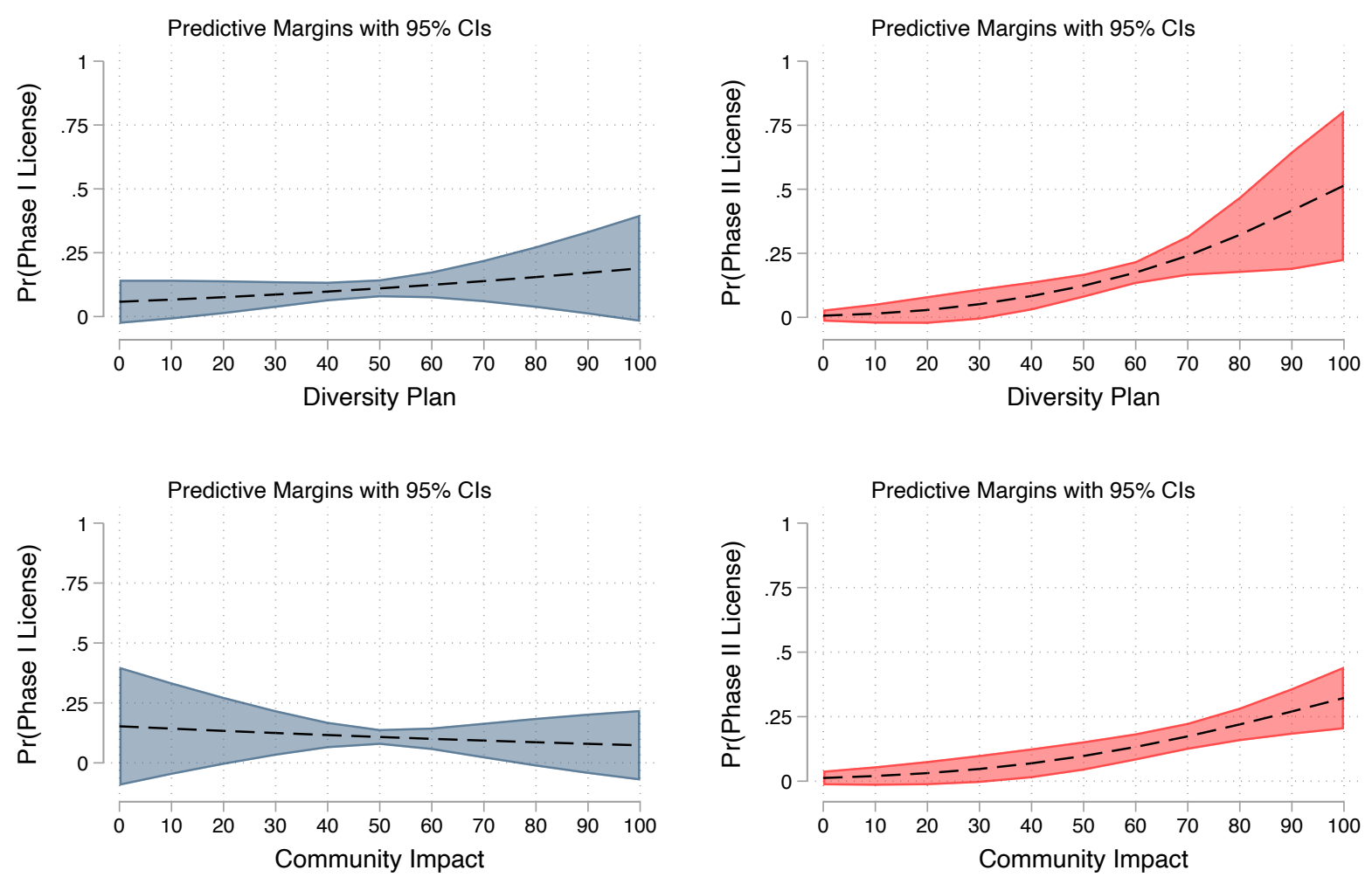
Figure 5: Predicted Probabilities of Winning Dispensary License based on Operations and Business Plans
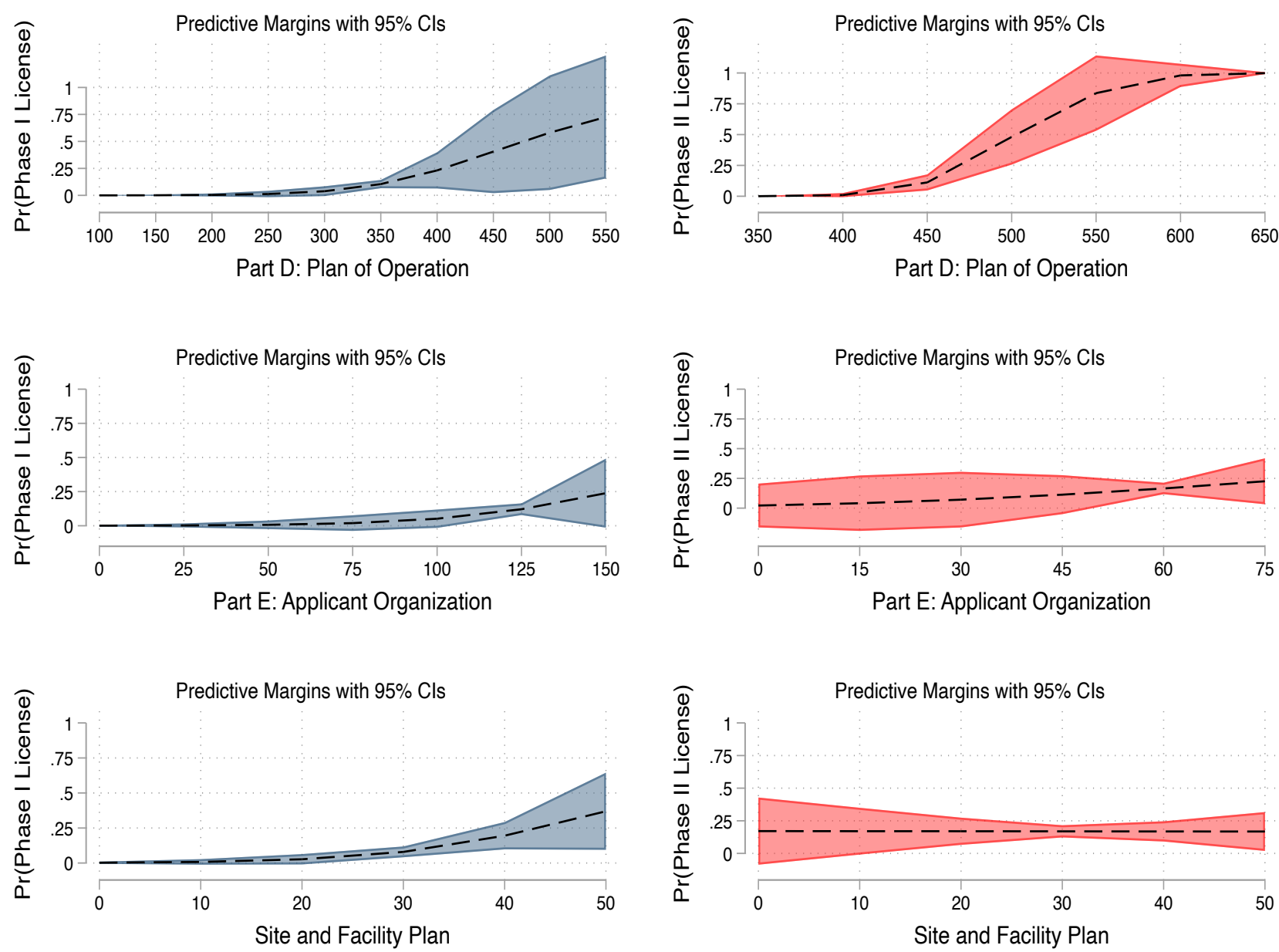

\section{DISCUSSION}

How do administrators weigh the four pillars of public administration when implementing public policy and how can scholars measure and assess the impact of social equity as a core pillar? This study offers insight into both questions. In terms of measurement, the scoring of medical cannabis dispensary license applications in Pennsylvania affords an opportunity to consider which factors were most important in the awarding of those licenses by reviewing the administrators' scores and awarding decisions. The scorecards explicitly allow for 
measuring the importance of social equity plans in license awarding. This approach offers a possible method for evaluating the relative weight of social equity provisions when included in scoring. Other policy arenas, such as higher education and health, have also used equity scorecards to examine the degree to which disparities may exist (Griffin, 2013, Park, Watson, and Galloway-Gilliam 2008). Scorecards can be useful and provide a clear method to examine certain aspects of social equity in other various policy initiatives.

Regarding dispensary licensing under Pennsylvania’s medical cannabis program, administrators in the PA DOH appeared to be strategic in their balancing of effectiveness and social equity. In Phase I of awarding, effectiveness was the clear criterion for awarding licenses. This is likely due to the necessity of standing up a brand-new program and industry quickly. Applicants with strong business plans and high marks for security and safety were the most likely to receive licenses. In Phase II, applicants were stronger in nearly every metric, on average, than those that applied in Phase I (see Table 2), including for their diversity plans. The fact that effectiveness was so important in the first round, combined with criticisms over the lack of diversity in awarding, may have both weeded out lower-scoring applicants and encouraged stronger diversity applications. Ultimately, diversity plans and community impact were significant factors in Phase II awarding. They did not supplant effectiveness, however. Those applicants with the highest scores on Part D: Operations were nearly guaranteed licenses (see Figure 5a), but diversity and community impact have significant effects on the probability of receiving a license.

While practical concerns about standing up an effective industry are one feasible explanation for the dominance of effectiveness in Phase I awarding, it is also possible that 
confusion existed among the measurement criteria between the pillars (Gooden and Myers 2004). In practice, there is a lack of standardization for cannabis license distributions. Not only was this a brand-new policy area for Pennsylvania, but cannabis regulations also differ vastly across state-legal programs (Klieger et al. 2017, Pacula, Hunt, and Boustead 2014). Policy learning most certainly occurs between states in this policy domain (Mallinson and Hannah 2020), but developing criteria that directly reflect each pillar remains elusive.

There are some limitations that exist within this work. First, we do not directly measure two of the pillars of public administration, efficiency or economy. Future research may examine these measures compared to social equity and effectiveness. Second, the use of scorecards for equity measurement itself has limitations. Scorecards tend to focus on policy outcomes and do not adequately gauge decision-making processes, assist with decision-making choice points to address inequity proactively, or include all aspects of social equity measurements. All aspects of social equity, including cultural competence acknowledgement and trainings and decisionmaking processes on the side of policy makers, were not examined. Therefore, future work may expand scorecards used here to include dimensions of decision-making and resource inputs that can contribute to equitable outcomes.

Nonetheless, this study offers several implications for theory and practice in public administration. A tangible measure of social equity in cannabis policies adds to the dearth of current research on social equity measurement for specific policies. This is particularly important as more states begin to address cannabis policies for license distributions. Through examination of Pennsylvania's medical cannabis policies and distributions, we can better understand the impact of a policy on socially vulnerable groups that have been harmed by laws in the past, 
contribute to industry diversity, and provide a clear method for measuring social equity against other public administration pillars.

\section{CONCLUSION}

Social equity is growing in its centrality to public administration as a profession (Guy and McCandless 2012), and across society more broadly. This is certainly the case for cannabis legalization in the United States. As some form of state-legal cannabis has reached nearly all the states, demands for restorative justice continue to grow louder. As one cannabis small business owner stated, "State and local governments had no problem finding the funds to carry out the war on drugs, and now they need to find the funds from day one to support social equity in the cannabis industry and restorative justice in the most impacted communities" (Worthy 2021). Thus, cannabis policy is a domain where public administrators, and scholars, can consider how to weigh oft competing goals. It is rare that policymakers and administrators can maximize all policy goals (Stone 2012). Measuring and assessing how administrators balance competing priorities is vital for maximizing attainment of our four pillars.

\section{ACKNOWLEDGEMENTS}

The authors would like to thank Erin Fisher and Eli Levine for excellent research assistance. This research was supported by the Drug Enforcement and Policy Center at the Ohio State Moritz College of Law. 


\section{REFERENCES}

Adinoff, Bryon, and Amanda Reiman. 2019. "Implementing social justice in the transition from illicit to legal cannabis." The American Journal of Drug and Alcohol Abuse 45 (6):673688. doi: 10.1080/00952990.2019.1674862.

Alexander, Jennifer, and Camilla Stivers. 2020. "Racial Bias: A Buried Cornerstone of the Administrative State." Administration \& Society 52 (10):1470-1490. doi: $10.1177 / 0095399720921508$.

Alexander, Michelle. 2010. The New Jim Crow: Mass Incarceration in the Age of Colorblindness. New York, NY: The New Press.

Baumgartner, Frank, Derek A. Epp, and Kelsey Shoub. 2018. Suspect Citizens. Cambridge: Cambridge University Press.

Blanchard, William. 1986. "Evaluating Social Equity: What Does Fairness Mean and Can We Measure It?" Policy Studies Journal 15 (1):29-54. doi: https://doi.org/10.1111/j.15410072.1986.tb00442.x.

Blessett, Brandi, Marc Fudge, and Tia Sherèe Gaynor. 2017. Moving from Theory to Practice: An Evaluative Assessment of Social Equity Approaches. Washington, DC: Center for Accountability and Performance and the National Academy for Public Administration's Standing Panel on Social Equity in Governance.

Blessett, Brandi, and Tia Sherèe Gaynor. 2017. "Choice Points asa Framework for DecisionMaking." In Leadership and Change in Public Sector Organizations, edited by James D. Ward. New York, NY: Routledge.

Bradbury, Mark, and J. Edward Kellough. 2011. "Representative Bureaucracy: Assessing the Evidence on Active Representation." The American Review of Public Administration 41 (2):157-167. doi: 10.1177/0275074010367823. 
Bryson, John M., Barbara C. Crosby, and Laura Bloomberg. 2014. "Public Value Governance: Moving Beyond Traditional Public Administration and the New Public Management." Public Administration Review 74 (4):445-456. doi: https://doi.org/10.1111/puar.12238.

Charbonneau, Etienne, Norma M. Riccucci, Gregg G. Van Ryzin, and Marc Holzer. 2009. "The Self-Reported Use of Social Equity Indicators in Urban Police Departments in the United States and Canada." State and Local Government Review 41 (2):95-107. doi:

10.1177/0160323x0904100203.

Couloumbis, Angela. 2017. "Pa. Officials Mum on Who Selected Medical Cannabis Growers." Philadelphia Inquirer, Last Modified June 20, 2017, accessed September 20, 2021. https://www.inquirer.com/philly/news/politics/state/pa-officials-mum-on-who-selectedmedical-cannabis-growers-20170620.html.

Durant, Robert F., and David H. Rosenbloom. 2017. "The Hollowing of American Public Administration." The American Review of Public Administration 47 (7):719-736. doi: $10.1177 / 0275074015627218$.

Frederickson, H. George. 1974. "Introductory Comments." Public Administration Review 34 (1):1-2.

Frederickson, H. George. 1990. "Public Administration and Social Equity." Public Administration Review 50 (2):228-237. doi: 10.2307/976870.

Frederickson, H. George. 2015. Social Equity and Public Administration: Origins, Developments, and Applications. New York: Routledge.

Frederickson, H. George. 2017. "Toward a New Public Administration." In Classics of Public Administration, edited by Jay M. Shafritz and Albert C. Hyde, 282-294. Boston, MA: Cengage Learning. 
Gooden, Susan, and Samuel L. Myers. 2004. "Social Equity in Public Affairs Education." Journal of Public Affairs Education 10 (2):91-97.

Gooden, Susan, and Shannon Portillo. 2011. "Advancing Social Equity in the Minnowbrook Tradition." Journal of Public Administration Research and Theory 21 (suppl_1):i61-i76. doi: 10.1093/jopart/muq067.

Gooden, Susan T. 2014. Race and Social Equity. New York, NY: Routledge.

Griffin, Kimberly A. "Confronting equity issues on campus: Implementing the equity scorecard in theory and practice ed. by Estela Bensimon, Lindsey Malcolm." Journal of College Student Development 54, no. 4 (2013): 449-451.

Guy, Mary E., and Sean A. McCandless. 2012. "Social Equity: Its Legacy, Its Promise." Public Administration Review 72:S5-S13.

Guy, Mary E., and Sean A. McCandless, eds. 2020. Achieving Social Equity: From Problems to Solutions. Irvine, CA: Melvin and Leigh Publishers.

House-Niamke, Stephanie, and Adam Eckerd. 2021. "Institutional Injustice: How Public Administration Has Fostered and Can Ameliorate Racial Disparities." Administration \& Society 53 (2):305-324. doi: 10.1177/0095399720979182.

Johnson, Norman J., and James H. Svara, eds. 2011. Justice for All. New York: Routledge.

Keiser, Lael R., Vicky M. Wilkins, Kenneth J. Meier, and Catherine A. Holland. 2002. "Lipstick and Logarithms: Gender, Institutional Context, and Representative Bureaucracy." The American Political Science Review 96 (3):553-564.

Kilmer, Beau. 2019. "How will cannabis legalization affect health, safety, and social equity outcomes? It largely depends on the 14 Ps." The American Journal of Drug and Alcohol Abuse 45 (6):664-672. doi: 10.1080/00952990.2019.1611841. 
Kilmer, Beau, and Erin Kilmer Neel. 2020. "Being thoughtful about cannabis legalization and social equity." World Psychiatry 19 (2):194-195. doi: https://doi.org/10.1002/wps.20741.

Klieger, Sarah B., Abraham Gutman, Leslie Allen, Rosalie Liccardo Pacula, Jennifer K. Ibrahim, and Scott Burris. 2017. "Mapping Medical Marijuana: State Laws Regulating Patients, Product Safety, Supply Chains and Dispensaries, 2017." Addiction 112 (12):2206-2216. doi: 10.1111/add.13910.

Koch, David W., Jaewon Lee, and Kyunghee Lee. 2016. "Coloring the War on Drugs: Arrest Disparities in Black, Brown, and White." Race and Social Problems 8 (4):313-325. doi: $10.1007 / \mathrm{s} 12552-016-9185-6$.

Krislov, Samuel, and David H. Rosenbloom. 1981. Representative Bureaucracy and the American Political System. New York: Praeger.

Mallinson, Daniel J., and A. Lee Hannah. 2020. "Policy and Political Learning: The Development of Medical Marijuana Policies in the States." Publius: The Journal of Federalism 50 (3):344-369. doi: 10.1093/publius/pjaa006.

Mallinson, Daniel J., A. Lee Hannah, and Gideon Cunningham. 2020. "The Consequences of Fickle Federal Policy: Administrative Hurdles for State Cannabis Policies." State and Local Government Review 52 (4):241-254. doi: 10.1177/0160323×20984540.

Meier, Kenneth J. 1993. "Representative Bureaucracy: A Theoretical and Empirical Exposition." In Research in Public Administration, edited by James L. Perry. New Greenwich, CT: JAI Press.

Mosher, Frederick. 1968. Democracy and the Public Service. Oxford, England: Oxford University Press. 
Neill Harris, Katherine, and William Martin. 2021. "Persistent Inequities in Cannabis Policy." Judges' Journal 60 (1):9-13.

Norman-Major, Kristen. 2011. "Balancing the Four Es; or Can We Achieve Equity for Social Equity in Public Administration?" Journal of Public Affairs Education 17 (2):233-252.

Pacula, Rosalie Liccardo, Priscillia Hunt, and Anne Boustead. 2014. "Words Can Be Deceiving: A Review of Variation Among Legally Effective Medical Marijuana Laws in the United States." Journal of drug policy analysis 7 (1):1-19. doi: 10.1515/jdpa-2014-0001.

Park, Annie, Nancy Watson, and Lark Galloway-Gilliam. "South Los Angeles health equity scorecard." Community Health Councils. Retrieved from http://chc-inc. org/downloads/South\% 20LA\% 20Scorecard. pdf(2008).

Riccucci, Norma M. 2009. "The Pursuit of Social Equity in the Federal Government: A Road Less Traveled?" Public Administration Review 69 (3):373-382. doi: https://doi.org/10.1111/j.1540-6210.2009.01984.x.

Riccucci, Norma M., and Gregg G. Van Ryzin. 2017. "Representative Bureaucracy: A Lever to Enhance Social Equity, Coproduction, and Democracy." Public Administration Review 77 (1):21-30. doi: https://doi.org/10.1111/puar.12649.

Schlozman, Kay Lehman, Sidney Verba, and Henry E. Brady. 1999. Civic Participation and the Equality Problem. Washington, DC: Brookings Institution Press.

Stone, Deborah. 2012. Policy Paradox. Third Edition ed. New York, NY: W. W. Norton \& Company.

Svara, James H., and James R. Brunet. 2005. "Social Equity Is a Pillar of Public Administration." Journal of Public Affairs Education 11 (3):253-258. 
Svara, James H., and James R. Brunet. 2020. "The Importance of Social Equity to Prevent a Hollow Public Administration." The American Review of Public Administration 50 (45):352-357. doi: 10.1177/0275074020910509.

Trochmann, Maren B. 2020. "How Administrative Rulemaking Can Advance Social Equity." In Achieving Social Equity: From Problems to Solutions, edited by Mary E. Guy and Sean A. McCandless, 158-171. Irvine, CA: Melvin and Leigh Publishers.

Twedt, Steve. 2018. "Round Two: Prospective Medical Marijuana Cultivators Take Another Shot." Pittsburgh Post-Gazette, Last Modified April 16, 2018, accessed September 20, 2021. https://www.post-gazette.com/business/healthcare-business/2018/04/15/medicalmarijuana-grower-processor-permit-Pennsylvania-application/stories/201804150032.

Wagaman, Andrew. 2017. "Medical Marijuana Appeals Expose Flaws in Application Scoring." The Morning Call, Last Modified September 23, 2017, accessed September 21, 2021. https://www.mcall.com/health/mc-biz-medical-marijuana-application-scoring-20170920story.html.

Warde, Bryan. 2013. "Black Male Disproportionality in the Criminal Justice Systems of the USA, Canada, and England: a Comparative Analysis of Incarceration." Journal of African American Studies 17 (4):461-479. doi: 10.1007/s12111-012-9235-0.

Weber, Max. 2017 [1922]. "Bureaucracy." In Classics of Public Administration, edited by Jay M. Shafritz and Albert C. Hyde, 63-67. Boston, MA: Cengage Learning. Weller, Christian E., and Angela Hanks. 2018. "The Widening Racial Wealth Gap in the United States after the Great Recession." Forum for Social Economics 47 (2):237-252. doi: 10.1080/07360932.2018.1451769. 
Wilson, Woodrow. 1887. "The Study of Administration." Political Science Quarterly 2 (2):197222.

Worthy, Patrice. 2021. "The Cannabis Industry is Booming, but for Many Black Americans the Price of Entry is Steep." The Guardian, Last Modified September 7, 2021, accessed September 20, 2021. https://www.theguardian.com/society/2021/sep/07/cannabisindustry-black-americans. 